\title{
Thermodynamic Behavior of Manganese 0xide in Lime-based Manganese Smelting Slags
}

\author{
Chang-Ho EOM, ${ }^{1)}$ Sung-Hee LEE, ${ }^{1)}$ Jin-Gyun PARK ${ }^{21}{ }^{2}$ Joo-Hyun PARK ${ }^{31 *}$ and Dong-Joon MIN ${ }^{1 / *}$ \\ 1) Department of Materials Science and Engineering, Yonsei University, Seoul, 03722 Korea. \\ 2) PosNEP Research Group, RIST, Pohang, 37673 Korea. \\ 3) Department of Materials Engineering, Hanyang University, Ansan, 15588 Korea.
}

(Received on April 30, 2015; accepted on October 14, 2015; J-STAGE Advance published date: December 3, 2015)

\begin{abstract}
The thermodynamic behavior of $\mathrm{MnO}$ in the $\mathrm{CaO}-\mathrm{SiO}_{2}-\mathrm{MnO}$ slag system of lower basicity to understand the smelting reduction of silicomanganese was investigated. Experimental results indicated that the activity coefficient of $\mathrm{MnO}$ was not affected by $\mathrm{MnO}$ content less than $30 \mathrm{~mol} \%$. However, it did in fact increase as the $\mathrm{MnO}$ content increased beyond $30 \mathrm{~mol} \%$ because the activity coefficient of $\mathrm{MnO}$ is closely associated with the silicate structure. The activity coefficient of $\mathrm{MnO}$ also increased with increasing basicity of slag and $\mathrm{MgO}$ content because of the free $\mathrm{O}^{2-}$ ions that are provided into the slag. On the other hand, the effect of the $\mathrm{Al}_{2} \mathrm{O}_{3}$ content on the activity coefficient of $\mathrm{MnO}$ was analyzed that the structure in the $\mathrm{CaO}-\mathrm{SiO}_{2}-\mathrm{MnO}-\mathrm{Al}_{2} \mathrm{O}_{3}$ system changes from that of a $\mathrm{Si}-\mathrm{O}-\mathrm{Si}$ linkage to that of $\mathrm{Si}-\mathrm{O}-\mathrm{Al}$ and $\mathrm{Al}-\mathrm{O}-\mathrm{Al}$ linkages as the content of $\mathrm{Al}_{2} \mathrm{O}_{3}$ increases. Structural considerations concerning the effect of slag composition on the activity coefficient of $\mathrm{MnO}$ are discussed in detail using Fourier transform infrared (FT-IR) spectroscopy. Finally, it is shown that manganese recovery can be increased by increasing the activity coefficient of $\mathrm{MnO}$ in the slag.
\end{abstract}

KEY WORDS: recovery; activity coefficient; manganese oxide; basicity; structure.

\section{Introduction}

Advanced high-strength steels with high manganese content, such as twinning-induced plasticity (TWIP)-assisted steel, have recently received attention because of their superior mechanical strength and formability. ${ }^{1,2)}$ Manganese is typically added in the form of ferromanganese (FeMn), which is produced either in an electric furnace or a submerged arc furnace using manganese ore or manganese nodules, with carbon as the reductant. During smelting, thermodynamic constraints necessitate the distribution of manganese into the FeMn slag in the form of $\mathrm{MnO}^{3)}$ Because approximately $30-40 \mathrm{wt} \% \mathrm{MnO}$ is typically present in the HCFeMn slag and is recycled by the silicomanganese ( $\mathrm{SiMn}$ ) smelting process, in which a minimization of manganese loss into the slag phase is an important issue to increase the overall efficiency of the smelting process. The possibility of recovering manganese from the manganese smelting slag, of which basicity is relatively high (i.e., $\mathrm{CaO} /$ $\mathrm{SiO}_{2}$ ratio $=1.6$ ), was confirmed by Aleksandrov et al. ${ }^{4}$ In order to achieve a higher recovery of manganese, several operating factors such as temperature, oxygen partial pressure, activity of $\mathrm{MnO}$ in the slag, and activity of $\mathrm{Mn}$ in the alloy should be carefully controlled. Because the activity

\footnotetext{
* Corresponding authors: E-mail: basicity@hanyang.ac.kr, chemical@yonsei.ac.kr DOI: http://dx.doi.org/10.2355/isijinternational.ISIJINT-2015-243
}

of $\mathrm{MnO}$ in the slag is known to be a dominant factor in determining the recovery of $\mathrm{Mn}$ into the alloy, the activity of $\mathrm{MnO}$ in the slag has been estimated by several researchers. $^{5-9)}$

Abraham et al. ${ }^{5)}$ estimated the activity of $\mathrm{MnO}$ in the $\mathrm{CaO}-\mathrm{SiO}_{2}-\mathrm{MnO}$ slag system, which increases with an increasing $\mathrm{MnO}$ content and $\mathrm{CaO} / \mathrm{SiO}_{2}$ ratio. Furthermore, the effect of basicity was reported by Simeonov and Sano, ${ }^{6}$ showing that the activity coefficient of $\mathrm{MnO}$ increases with increasing content of basic oxides such as $\mathrm{CaO}, \mathrm{BaO}$, and $\mathrm{Na}_{2} \mathrm{O}$ in the highly basic (i.e., $\mathrm{CaO} / \mathrm{SiO}_{2}>3.0$ ) slags. In order to understand the thermodynamic behavior of $\mathrm{MnO}$ in steelmaking slag (for which $\mathrm{FeO}=5-20 \mathrm{wt} \%$ and $\mathrm{CaO} /$ $\mathrm{SiO}_{2}$ ratio $\left.>1.5\right)$, the coupled reaction of manganese and iron, viz. $(\mathrm{FeO})+[\mathrm{Mn}]=(\mathrm{MnO})+\mathrm{Fe}$, at the slag-metal interface has been investigated. ${ }^{7-9)}$ It has been shown that the equilibrium distribution ratio of $\mathrm{Mn}, \mathrm{L}_{\mathrm{Mn}}=(\% \mathrm{Mn}) /$ $[\% \mathrm{Mn}]$, decreases as the basicity of slag increases because the ratio of the activity coefficient of oxides $\gamma_{\mathrm{MnO}} / \gamma_{\mathrm{FeO}}$ increases with increasing basicity. Consequently, the $\mathrm{MnO}$ in the slag plays the role of a basic oxide, and thus the activity coefficient of $\mathrm{MnO}$ is strongly affected by the basicity of the slag. However, the effect of $\mathrm{MgO}$ and $\mathrm{Al}_{2} \mathrm{O}_{3}$ content on the activity coefficient of $\mathrm{MnO}$ in slags with lower amounts of $\mathrm{FeO}$ is relatively few, even though it constitutes a very important factor in determining the $\mathrm{Mn}$ recovery during the SiMn smelting process.

Furthermore, Abraham et al. ${ }^{5)}$ have reported that the 
activity coefficient of $\mathrm{MnO}$ in the $\mathrm{CaO}-\mathrm{SiO}_{2}-\mathrm{MnO}$ ternary system is closely associated with the $\mathrm{SiO}_{2}$ content. This can be explained by the fact that the manganese $\left(\mathrm{Mn}^{2+}\right)$ tends to associate with $\mathrm{O}^{2-}$ and/or $\mathrm{SiO}_{4}{ }^{4-}$ ions in the silicate structure. The organic relationships between the silicate structure and the thermodynamic properties of oxide melts such as the mixing free energy of silicates and sulfide capacity have been reported. ${ }^{10,11)}$ In particular, Park ${ }^{12,13)}$ demonstrated that the sulfide capacity is strongly affected by the structure of the $\mathrm{CaO}-\mathrm{SiO}_{2}-\mathrm{MnO}$ system, and that the excess free energy of $\mathrm{MnO}$ is inversely proportional to the degree of polymerization by employing Raman spectra analysis in conjunction with a computational thermodynamic assessment. Therefore, the influence of the silicate structure on the activity coefficient of $\mathrm{MnO}$ should be thoroughly investigated.

In the present study, the effects of the $\mathrm{MnO}$ content, basicity $\left(\mathrm{CaO} / \mathrm{SiO}_{2}\right.$ ratio), as well as the $\mathrm{MgO}$ and $\mathrm{Al}_{2} \mathrm{O}_{3}$ content on the activity coefficient of $\mathrm{MnO}$ in the $\mathrm{CaO}-$ $\mathrm{SiO}_{2}-\mathrm{MnO}\left(-\mathrm{Al}_{2} \mathrm{O}_{3}, \mathrm{MgO}\right)$ slag systems, are investigated. To understand the structural aspects of the slag, which influences the thermodynamic behavior of $\mathrm{MnO}$, Fourier transform infrared (FT-IR) spectroscopy is employed using quenched slag samples.

\section{Experimental Methods and Procedures}

\subsection{Experimental}

A thermochemical equilibration technique was used for measuring the activity coefficient of $\mathrm{MnO}$ in the $\mathrm{CaO}-\mathrm{SiO}_{2}-$ $\mathrm{MnO}\left(-\mathrm{MgO}, \mathrm{Al}_{2} \mathrm{O}_{3}\right)$ slag in equilibrium with a molten $\mathrm{Cu}$ or $\mathrm{Fe}-\mathrm{C}$ melt. A vertical super kanthal $\left(\mathrm{MoSi}_{2}\right)$ furnace with a mullite reaction tube was used, as shown in Fig. 1. The temperature was controlled within $\pm 2 \mathrm{~K}$ by using a calibrated R-type (Pt-13 mass\% Rh/Pt) thermocouple and a proportional integral differential controller. The slag samples were prepared using reagent-grade $\mathrm{SiO}_{2}, \mathrm{MnO}$, $\mathrm{MgO}, \mathrm{Al}_{2} \mathrm{O}_{3}$, and $\mathrm{CaCO}_{3}$. $\mathrm{CaCO}_{3}$ was calcined to $\mathrm{CaO}$ by heating at $1273 \mathrm{~K}$ for $6 \mathrm{~h} .5 \mathrm{~g}$ of the slag sample and $5 \mathrm{~g}$ of the $\mathrm{Cu}$ or $\mathrm{Fe}-\mathrm{C}$ system were placed in a molybdenum or graphite crucible, respectively $(15 \mathrm{~mm}$ ID $\times 18 \mathrm{~mm}$ OD $\times$ $50 \mathrm{~mm} \mathrm{H}$ ), and the oxygen partial pressure was controlled (which is described in detail in the following sections). Equilibration times of $12 \mathrm{~h}$ for slag/ $\mathrm{Cu}$ under a $\mathrm{CO}-\mathrm{CO}_{2}$

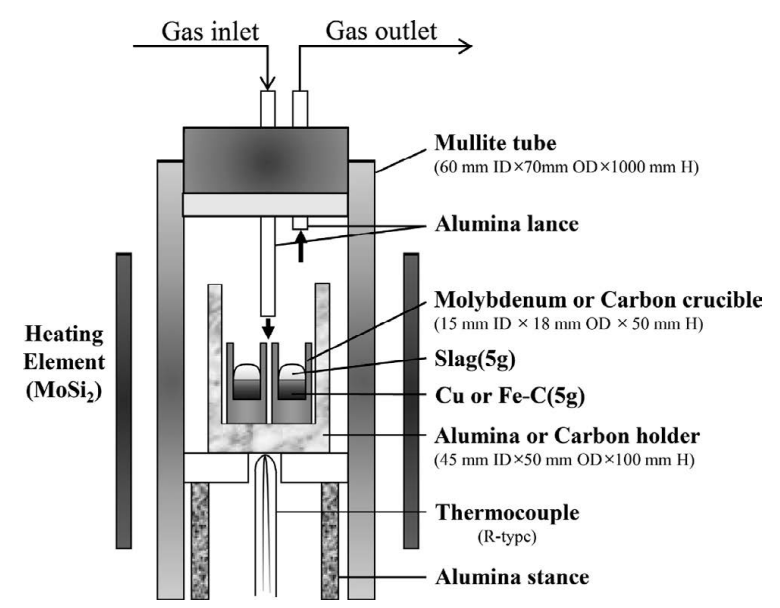

Fig. 1. Schematic diagram of the experimental apparatus for smelting reduction. atmosphere $\left(\mathrm{CO} / \mathrm{CO}_{2}=9 / 1\right)$, and $24 \mathrm{~h}$ for slag $/ \mathrm{Fe}-\mathrm{C}$ under a $\mathrm{CO}$ gas atmosphere coexisted with $\mathrm{C}$, were determined from preliminary experiments.

After equilibration, the samples were removed from the furnace and quenched by Ar flushing. The metal and slag were carefully separated and then analyzed. The carbon content of the metals after the experiments was determined using a C/S combustion analyzer (C/S, CS-200; LECO, St. Joseph, MI, USA). The concentration of Mn in the metal was measured with an inductively coupled plasma optical emission spectrometer (ICP-OES; Agilent Technologies, Santa Clara, CA, USA). The slag composition was determined using X-ray fluorescence spectroscopy (XRF, S4 Explorer; Bruker AXS, Madison, WI, USA); the equilibrium compositions are listed in Tables $\mathbf{1}$ and $\mathbf{2}$. The slag structure was then investigated by Fourier transform infrared (FT-IR) spectroscopy (Spectra100; Perkin-Elmer, Waltham, MA, USA). The details for glass sample preparation and FT-IR analysis procedures are provided elsewhere. ${ }^{14)}$

\subsection{Determination of Activity Coefficient of $\mathrm{MnO}$ in $\mathrm{CaO}-\mathrm{SiO}_{2}-\mathrm{MnO}$ Slag}

The activity coefficient of $\mathrm{MnO}$ in the $\mathrm{CaO}-\mathrm{SiO}_{2}-\mathrm{MnO}$ ternary slag was measured by equilibrating the slag and molten $\mathrm{Cu}$ using a Mo crucible under a $\mathrm{CO}-\mathrm{CO}_{2}$ atmosphere $\left(\mathrm{CO} / \mathrm{CO}_{2}=9 / 1\right)$ at $1773 \mathrm{~K}$, for which the oxygen partial pressure was $\mathrm{p}_{\mathrm{O}_{2}}=2.75 \times 10^{-10} \mathrm{~atm}$. The equilibrium reaction and the activity coefficient of $\mathrm{MnO}$ in the slag can be expressed as follows: ${ }^{15}$ )

$$
\begin{gathered}
M n O(s)+C O(g)=M n(l)+C_{2}(g), \\
\Delta G^{\circ}=120039+0.96 T(\mathrm{~J} / \mathrm{mole} \cdot \mathrm{K}) \\
\gamma_{M n O}=\gamma_{M n}^{o} \cdot \frac{\left[X_{M n}\right]}{\left(X_{M n O}\right)} \cdot \frac{p_{C O_{2}}}{p_{C O}} \cdot \frac{1}{K_{1}}, \ldots .
\end{gathered}
$$

where $\gamma_{M n O}$ is the activity coefficient of $\mathrm{MnO}$ in the slag, $\gamma_{M n}^{o}$ is the activity coefficient of $\mathrm{Mn}$ in molten $\mathrm{Cu}$, and $X_{\mathrm{MnO}}$ and $X_{\mathrm{Mn}}$ are the mole fractions of $\mathrm{MnO}$ in the slag and $\mathrm{Mn}$ in the alloy, respectively. The activity coefficient of $\mathrm{Mn}$ in molten $\mathrm{Cu}$ was measured by Jung ${ }^{16)}$ to be $\gamma_{M n}^{o}=0.324$ at $1773 \mathrm{~K}$. The activity coefficient of $\mathrm{MnO}$ estimated by Eq. (2) in the present study agrees well with previous results ${ }^{5}$ ) measured by the equilibration between $\mathrm{Pt}$ foil and $\mathrm{CaO}-$ $\mathrm{SiO}_{2}-\mathrm{MnO}$ slag at $1773 \mathrm{~K}$, as shown in Fig. 2. The activity coefficient of $\mathrm{MnO}$ was measured by equilibrating the slag and molten $\mathrm{Cu}$ in the present study.

\section{Results}

The effect of the MnO content on the activity coefficient of $\mathrm{MnO}$ at $1773 \mathrm{~K}$ is shown in Fig. 2. The activity coefficient of $\mathrm{MnO}, \gamma_{\mathrm{MnO}}$, is not affected by its own concentration up to about $30 \mathrm{~mol} \% \mathrm{MnO}$, beyond which it slightly increases at a $\mathrm{CaO} / \mathrm{SiO}_{2}$ ratio of 0.54 . This tendency is very similar to Abraham et al.'s result, ${ }^{5)}$ in which the inflection point is dependent on the $\mathrm{CaO} / \mathrm{SiO}_{2}$ ratio. This possibly originates from the fact that the structure of the slag melt is affected by the $\mathrm{CaO} / \mathrm{SiO}_{2}$ ratio.

The effect of the modified basicity (B), which is defined as the $(\% \mathrm{CaO}+\% \mathrm{MgO}+\% \mathrm{FeO}) / \% \mathrm{SiO}_{2}$ ratio on the activ- 
ISIJ International, Vol. 56 (2016), No. 1

Table 1. Experimental result for the composition of slag and $\mathrm{Cu}$.

$(\mathrm{mol} \%)$

\begin{tabular}{|c|c|c|c|c|c|c|c|c|c|c|c|c|}
\hline \multirow{2}{*}{ No. } & \multirow{2}{*}{ Crucible } & \multirow{2}{*}{ Gas } & \multirow{2}{*}{ Base metal } & \multirow{2}{*}{$\frac{\text { alloy }}{\mathrm{Mn}}$} & \multicolumn{8}{|c|}{ slag } \\
\hline & & & & & $\mathrm{CaO}$ & $\mathrm{SiO}_{2}$ & $\mathrm{MnO}$ & $\mathrm{CuO}$ & $\mathrm{MoO}_{3}$ & $\mathrm{MgO}$ & $\mathrm{Al}_{2} \mathrm{O}_{3}$ & $\mathrm{C} / \mathrm{S}$ \\
\hline 1 & & & & 0.0283 & 31.94 & 59.24 & 8.47 & 0.25 & 0.08 & - & - & 0.54 \\
\hline 2 & & & & 0.0716 & 28.66 & 54.22 & 16.82 & 0.21 & 0.09 & - & - & 0.53 \\
\hline 3 & & & & 0.0694 & 28.97 & 53.61 & 17.07 & 0.27 & 0.08 & - & - & 0.54 \\
\hline 4 & & & & 0.1064 & 25.98 & 47.48 & 26.00 & 0.37 & 0.17 & - & - & 0.55 \\
\hline 5 & & & & 0.138 & 24.10 & 44.71 & 30.66 & 0.31 & 0.22 & - & - & 0.54 \\
\hline 6 & & & & 0.2065 & 22.88 & 41.22 & 35.12 & 0.35 & 0.37 & - & - & 0.56 \\
\hline 7 & & & & 0.379 & 19.25 & 34.84 & 44.78 & 0.33 & 0.79 & - & - & 0.55 \\
\hline 8 & & & & 0.6826 & 15.59 & 28.64 & 53.43 & 0.35 & 1.99 & - & - & 0.54 \\
\hline 9 & & & & 0.0341 & 36.68 & 56.22 & 6.82 & 0.21 & 0.07 & - & - & 0.65 \\
\hline 10 & & & & 0.0769 & 43.63 & 49.25 & 6.61 & 0.20 & 0.31 & - & - & 0.89 \\
\hline 11 & & & $\mathrm{C}_{1}$ & 0.0811 & 48.39 & 44.50 & 6.80 & 0.14 & 0.17 & - & - & 1.09 \\
\hline 12 & VIO & & $\mathrm{Cu}$ & 0.129 & 52.61 & 39.94 & 6.92 & 0.11 & 0.42 & - & - & 1.32 \\
\hline 13 & & & & 0.0447 & 35.19 & 50.94 & 6.69 & 0.19 & 0.05 & 6.93 & - & 0.69 \\
\hline 14 & & & & 0.0476 & 31.52 & 46.50 & 6.75 & 0.26 & 0.09 & 14.88 & - & 0.68 \\
\hline 15 & & & & 0.0526 & 28.80 & 43.29 & 6.27 & 0.15 & 0.26 & 21.23 & - & 0.67 \\
\hline 16 & & & & 0.0774 & 26.53 & 38.97 & 6.09 & 0.11 & 0.28 & 28.03 & - & 0.68 \\
\hline 17 & & & & 0.0451 & 35.50 & 53.61 & 6.93 & 0.28 & 0.22 & - & 3.47 & 0.66 \\
\hline 18 & & & & 0.0511 & 34.03 & 50.68 & 6.96 & 0.41 & 0.79 & - & 7.14 & 0.67 \\
\hline 19 & & & & 0.0629 & 33.02 & 47.77 & 7.41 & 0.37 & 0.18 & - & 11.24 & 0.69 \\
\hline 20 & & & & 0.07 & 30.96 & 46.43 & 7.52 & 0.17 & 0.22 & - & 14.69 & 0.67 \\
\hline 21 & & & & 0.0753 & 28.03 & 42.58 & 8.19 & 0.20 & 0.05 & - & 20.96 & 0.66 \\
\hline 22 & & & & 0.0698 & 27.52 & 41.09 & 7.80 & 0.26 & 0.08 & - & 23.25 & 0.67 \\
\hline
\end{tabular}

Table 2. Experimental result for the composition of slag and $\mathrm{Fe}-\mathrm{Mn}-\mathrm{Si}-\mathrm{C}$.

$(\mathrm{mol} \%)$

\begin{tabular}{|c|c|c|c|c|c|c|c|c|c|c|c|c|c|}
\hline \multirow{2}{*}{ No. } & \multirow{2}{*}{ Crucible } & \multirow{2}{*}{ Gas } & \multirow{2}{*}{ Base metal } & \multicolumn{3}{|c|}{ alloy } & \multicolumn{7}{|c|}{ slag } \\
\hline & & & & $\mathrm{Mn}$ & $\mathrm{C}$ & $\mathrm{Si}$ & $\mathrm{CaO}$ & $\mathrm{SiO}_{2}$ & $\mathrm{MnO}$ & $\mathrm{FeO}$ & $\mathrm{MgO}$ & $\mathrm{Al}_{2} \mathrm{O}_{3}$ & $\mathrm{C} / \mathrm{S}$ \\
\hline 1 & & & & 4.68 & 17.93 & 6.06 & 38.03 & 51.43 & 10.28 & 0.27 & - & - & 0.74 \\
\hline 2 & & & & 4.35 & 17.67 & 6.57 & 42.17 & 49.27 & 8.34 & 0.22 & - & - & 0.86 \\
\hline 3 & & & & 4.79 & 18.58 & 6.02 & 48.08 & 45.40 & 6.35 & 0.17 & - & - & 1.06 \\
\hline 4 & & & & 5.39 & 20.32 & 4.45 & 54.61 & 41.98 & 3.27 & 0.14 & - & - & 1.30 \\
\hline 5 & & & & 5.65 & 18.58 & 3.45 & 34.08 & 50.70 & 14.74 & 0.48 & - & - & 0.67 \\
\hline 6 & & & & 6.56 & 19.24 & 1.67 & 31.55 & 48.56 & 19.41 & 0.48 & - & - & 0.65 \\
\hline 7 & & & & 12.23 & 19.99 & 1.41 & 27.81 & 44.80 & 27.01 & 0.37 & - & - & 0.62 \\
\hline 8 & & & & 4.26 & 18.49 & 3.98 & 34.72 & 48.27 & 8.49 & 0.18 & 8.33 & - & 0.72 \\
\hline 9 & $\mathrm{C}$ & $\mathrm{C}-\mathrm{CO}$ & $\mathrm{Fe}$ & 4.17 & 18.56 & 4.16 & 31.13 & 45.70 & 6.92 & 0.17 & 16.08 & - & 0.68 \\
\hline 10 & & & & 4.38 & 19.20 & 2.71 & 28.45 & 43.41 & 5.24 & 0.16 & 22.74 & - & 0.66 \\
\hline 11 & & & & 4.04 & 19.72 & 2.23 & 25.59 & 40.92 & 3.91 & 0.15 & 29.44 & - & 0.63 \\
\hline 12 & & & & 4.60 & 18.15 & 3.95 & 37.41 & 50.22 & 8.23 & 0.19 & - & 3.95 & 0.74 \\
\hline 13 & & & & 4.61 & 19.31 & 3.95 & 35.41 & 49.71 & 7.31 & 0 & - & 7.57 & 0.71 \\
\hline 14 & & & & 4.48 & 19.52 & 3.04 & 34.48 & 48.01 & 5.53 & 0.20 & - & 11.78 & 0.72 \\
\hline 15 & & & & 3.89 & 18.65 & 3.21 & 34.36 & 46.10 & 3.97 & 0.28 & - & 15.28 & 0.75 \\
\hline 16 & & & & 3.80 & 19.76 & 4.49 & 31.84 & 47.13 & 5.25 & 0.241 & - & 15.54 & 0.68 \\
\hline 17 & & & & 4.16 & 14.30 & 3.77 & 31.71 & 43.69 & 3.82 & 0.24 & - & 20.53 & 0.73 \\
\hline
\end{tabular}




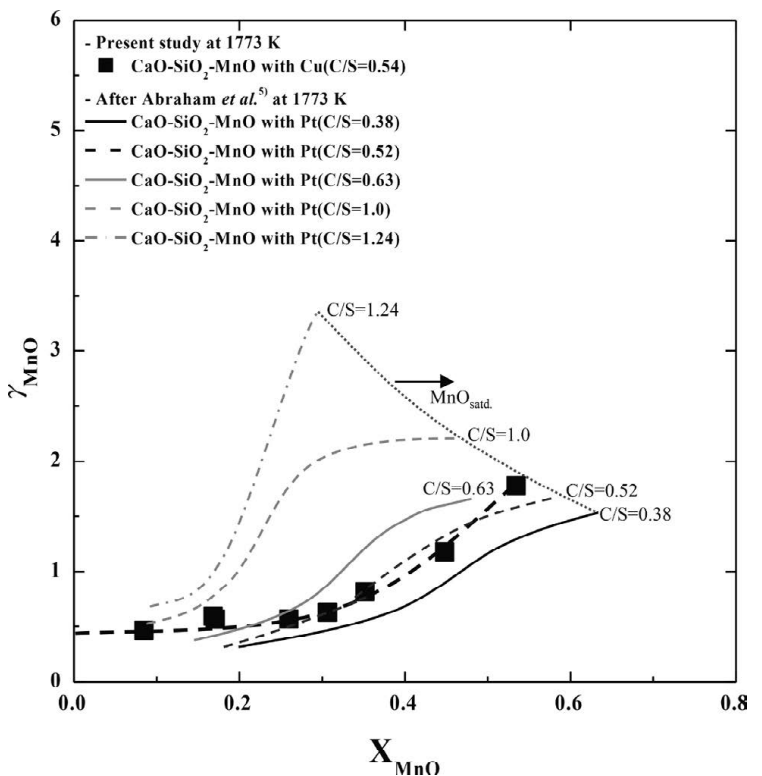

Fig. 2. The effect of $\mathrm{MnO}$ concentration on activity coefficient of $\mathrm{MnO}$ in $\mathrm{CaO}-\mathrm{SiO}_{2}-\mathrm{MnO}$ system at $1773 \mathrm{~K}$.

ity coefficient of $\mathrm{MnO}$ is shown in Fig. 3. The activity coefficient of $\mathrm{MnO}$ increases as a function of the modified basicity, indicating that $\mathrm{MnO}$ is a basic oxide in the slag. There are qualitatively similar tendencies in the works of Abraham et al., ${ }^{5)}$ Jung et al., ${ }^{17)}$ Sobandi et al., ${ }^{18)}$ and the present authors for a modified basicity region of lower than 1.5. However, Suito and Inoue ${ }^{8)}$ as well as Simeonove and $\mathrm{Sano}^{6)}$ carried out experiments at the higher modified basicity region of $\mathrm{B}>2.0$. It is interesting that the basicity dependency of $\gamma_{\mathrm{MnO}}$ is different in accordance with slag system. The basicity dependency of $\gamma_{\mathrm{MnO}}$ in the $\mathrm{CaO}-\mathrm{SiO}_{2}-$ $\mathrm{MnO}(-\mathrm{MgO})$ system is more significant than that in the $\mathrm{FeO}_{-}{ }^{8)}$ or $\mathrm{CaF}_{2-}{ }^{-6}$ systems.

The effects of $\mathrm{MgO}$ and $\mathrm{Al}_{2} \mathrm{O}_{3}$ on the activity coefficient of $\mathrm{MnO}$ in the $\mathrm{CaO}-\mathrm{SiO}_{2}-\mathrm{MnO}-\mathrm{MgO}$ and $\mathrm{CaO}-\mathrm{SiO}_{2}-$ $\mathrm{MnO}-\mathrm{Al}_{2} \mathrm{O}_{3}$ slags at $\mathrm{CaO} / \mathrm{SiO}_{2}=0.67$ are shown in Fig. 4. The activity coefficient of $\mathrm{MnO}$ increases with increasing content of $\mathrm{MgO}$ and $\mathrm{Al}_{2} \mathrm{O}_{3}$ up to about $20 \mathrm{~mol} \%$. Meanwhile, the effect of $\mathrm{MgO}$ on the activity coefficient of $\mathrm{MnO}$ is magnified at higher $\mathrm{MgO}$ region due to changing from the (pseudo-) wollastonite primary area to the diopside primary area, where phases are the silicate structure. Otherwise, in case of $\mathrm{Al}_{2} \mathrm{O}_{3}$ containing slag system, the activity coefficient of $\mathrm{MnO}$ decrease with increasing content of $\mathrm{Al}_{2} \mathrm{O}_{3}$ at higher $\mathrm{Al}_{2} \mathrm{O}_{3}$ region because the (pseudo-) anorthite primary area of the aluminosilicate structure is changed to the (pseudo-) Al-spinel primary area of the aluminate structure. Thus, the dominant reason for this behavior is independent from thermodynamic and structural viewpoints. In point of fact, the $\mathrm{MgO}$ simply provides free $\mathrm{O}^{2-}$ ions into the slag as likely as $\mathrm{CaO}$, resulting in the depolymerization of silicate melts. However, the effect of $\mathrm{Al}_{2} \mathrm{O}_{3}$ is more complicated than the effect of $\mathrm{MgO}$ in view of the aluminosilicate structure. Moreover, the activity coefficient of $\mathrm{MnO}$ in the $\mathrm{CaO}-\mathrm{SiO}_{2}-$ $\mathrm{MnO}-\mathrm{Al}_{2} \mathrm{O}_{3}$ system decreases for $\mathrm{Al}_{2} \mathrm{O}_{3}$ contents greater than about $20 \mathrm{~mol} \%$ because the $\mathrm{Mn}^{2+}$ ions are balanced with aluminate anions at higher $\mathrm{Al}_{2} \mathrm{O}_{3}$ region. A more detailed analysis of the structural effect of $\mathrm{MgO}$ and $\mathrm{Al}_{2} \mathrm{O}_{3}$ on $\gamma_{M n O}$ is discussed in the following section.

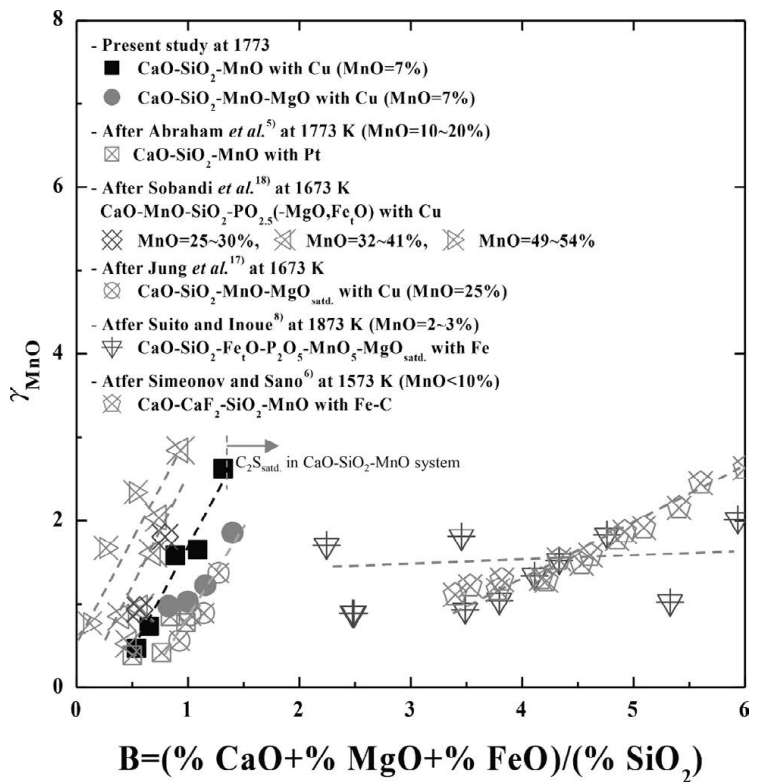

Fig. 3. The effect of slag basicity on the activity coefficient of manganese in $\mathrm{CaO}-\mathrm{SiO}_{2}-\mathrm{MnO}(-\mathrm{MgO})$ at $1773 \mathrm{~K}$.

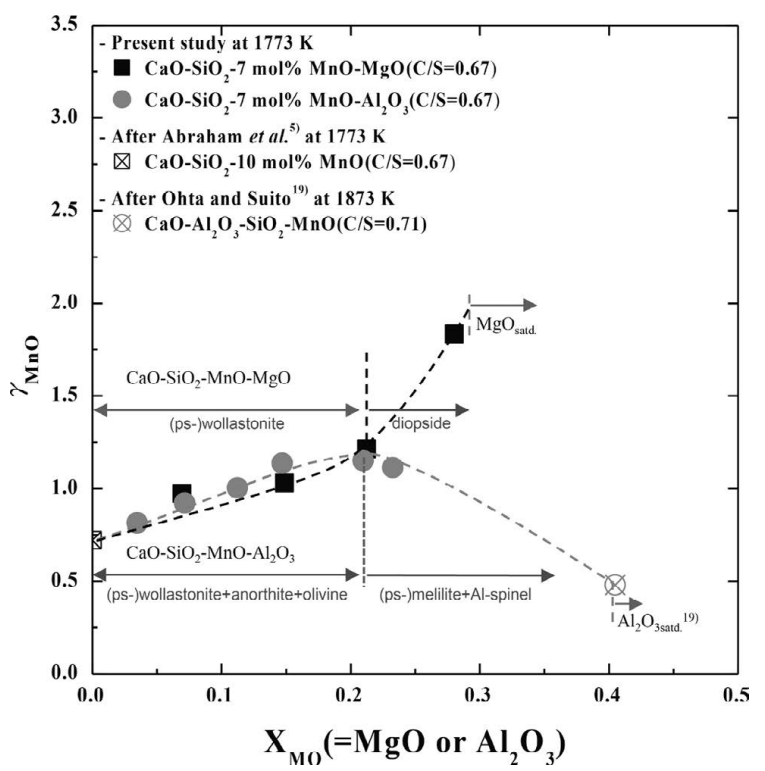

Fig. 4. The effect of mole fraction of $\mathrm{MgO}$ and $\mathrm{Al}_{2} \mathrm{O}_{3}$ on the activity coefficient of $\mathrm{MnO}$ in $\mathrm{CaO}-\mathrm{SiO}_{2}-\mathrm{MnO}\left(-\mathrm{MgO}, \mathrm{Al}_{2} \mathrm{O}_{3}\right)$ at $1773 \mathrm{~K}$.

\section{Discussion}

\subsection{Structure of the $\mathrm{CaO}-\mathrm{SiO}_{2}-\mathrm{MnO}$ Slag}

The activity coefficient of $\mathrm{MnO}$ in silicate melts is known to be affected by silicate structure because the relative stability of oxide components in multicomponent silicate melts is strongly dependent on the degree of polymerization and the network-modifying role of cations. ${ }^{20)}$ The non-bridging oxygen (NBO) in silicate melts can be categorized into the following units: $\mathrm{Q}^{4}(\mathrm{NBO} / \mathrm{Si}=0$, fully polymerized $), \mathrm{Q}^{3}$ $(\mathrm{NBO} / \mathrm{Si}=1$, sheet $), \mathrm{Q}^{2}(\mathrm{NBO} / \mathrm{Si}=2$, chain $), \mathrm{Q}^{1}(\mathrm{NBO} /$ $\mathrm{Si}=3$, dimer $)$, and $\mathrm{Q}^{0}(\mathrm{NBO} / \mathrm{Si}=4$, monomer $)$. A singly charged site $\mathrm{Q}^{3}$ provides a site for one $\mathrm{M}^{+}$, whereas the doubly charged site $\mathrm{Q}^{2}$ may accommodate one $\mathrm{M}^{2+}$, or two $\mathrm{M}^{+}$cations. Furthermore, divalent cations $\mathrm{M}^{2+}$ of large 
ionic radius should preferentially occupy the more open $\mathrm{Q}^{3}$ sites, whereas the smaller $\mathrm{M}^{2+}$ cations will favor the higher charge concentration offered by the $\mathrm{Q}^{2}$ sites. ${ }^{21)}$ Because the ionization potential of $\mathrm{Ca}^{2+}\left(\mathrm{Z} / \mathrm{r}^{2}=2\right)$ is lower than that of $\mathrm{Mn}^{2+}\left(\mathrm{Z} / \mathrm{r}^{2}=2.4\right.$ to 3.0, depending on the electron's spin $){ }^{21)}$ the $\mathrm{Ca}^{2+}$ ion is charge balanced with two open $\mathrm{O}^{-}$ions, whereas the $\mathrm{Mn}^{2+}$ ion is balanced with two adjacent cornershared $\mathrm{O}^{-}$ions. $^{20)}$

The relationship between the activity coefficient of $\mathrm{MnO}$ and the relative abundance of structural units in the $\mathrm{CaO}-$ $\mathrm{SiO}_{2}-\mathrm{MnO}$ slag system is shown in Fig. 5. ${ }^{20)}$ According to Park, ${ }^{20)}$ the silicate structure is depolymerized by the addition of $\mathrm{MnO}$ in the $\mathrm{CaO}-\mathrm{SiO}_{2}-\mathrm{MnO}\left(\mathrm{CaO} / \mathrm{SiO}_{2}\right.$ ratio $=$ $0.5)$ system. In particular, the relative fraction of the $Q^{2}$ unit increases dramatically with the increasing $\mathrm{MnO}$ concentration. Since $\mathrm{Mn}^{2+}$ should be balanced with $\mathrm{Q}^{2}$ corner-shared $\mathrm{O}^{-}$ions, free $\mathrm{Mn}^{2+}$ cations should be nearly unchanged in spite of increasing $\mathrm{MnO}$ concentration. Thus, the activity coefficient of $\mathrm{MnO}$ is almost constant. Then, the activity coefficient of $\mathrm{MnO}$ increases by increasing the content of $\mathrm{MnO}$ because the relative fraction of the $\mathrm{Q}^{2}$ unit drastically decreases for $\mathrm{MnO}$ content greater than about $35 \mathrm{~mol} \%$. A more detailed analysis for the depolymerization reaction of silicate melts by the addition of $\mathrm{MnO}$ is available in previous study. ${ }^{20)}$

The IR transmittance of the $\mathrm{CaO}-\mathrm{SiO}_{2}-7 \mathrm{~mol} \% \mathrm{MnO}$ slag is shown as a function of the wavenumbers $\left(\mathrm{cm}^{-1}\right)$ at various $\mathrm{CaO} / \mathrm{SiO}_{2}$ ratios in Fig. 6. In general, the bands at $1150-750 \mathrm{~cm}^{-1}$ and $480 \mathrm{~cm}^{-1}$ correspond to the symmetric $\mathrm{Si}-\mathrm{O}$ stretching vibration with various $\mathrm{NBO} / \mathrm{Si}$ and the rocking bridging oxygen vibration mode of the $\mathrm{Si}-\mathrm{O}-\mathrm{Si}$ bond, respectively. The IR bands in the former range are categorized into four groups (i.e., 1 090, 990, 920, and 870 $\mathrm{cm}^{-1}$ ), which are typically assigned to $\mathrm{NBO} / \mathrm{Si}=1,2,3$, and $4,{ }^{14,20,22,23)}$ respectively. The symmetric $\mathrm{Si}-\mathrm{O}$ stretching bonds at $1150-800 \mathrm{~cm}^{-1}$ for the $\mathrm{CaO} / \mathrm{SiO}_{2}$ ratio $=0.65$ system shift to $1150-730 \mathrm{~cm}^{-1}$ for the $\mathrm{CaO} / \mathrm{SiO}_{2}$ ratio $=1.32$ system. The shifting of the symmetric $\mathrm{Si}-\mathrm{O}$ stretching bands

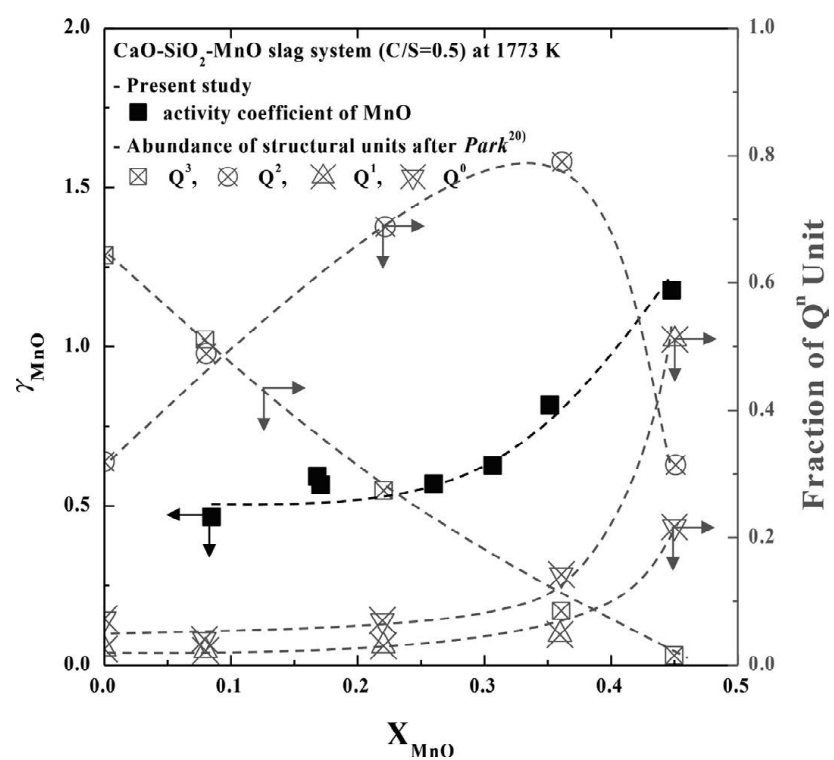

Fig. 5. The relationship between activity coefficient of $\mathrm{MnO}$ and abundance of structural units in $\mathrm{CaO}-\mathrm{SiO}_{2}-\mathrm{MnO}$ slag system. $^{20)}$ towards the lower wavenumbers indicates that the $\mathrm{NBO} /$ $\mathrm{Si}=4\left(\mathrm{Q}^{0}\right)$ unit becomes more pronounced by increasing the $\mathrm{CaO} / \mathrm{SiO}_{2}$ ratio. This means that the silicate network is more depolymerized by increasing the $\mathrm{CaO} / \mathrm{SiO}_{2}$ ratio. This is similar to Park's result, ${ }^{20)}$ in which analysis of the Raman spectra shows that the $\mathrm{Q}^{2}$ and $\mathrm{Q}^{0}$ units gradually increase with an increasing $\mathrm{CaO} / \mathrm{SiO}_{2}$ ratio in the $\mathrm{CaO}-\mathrm{SiO}_{2}-\mathrm{MnO}$ slag. Therefore, an increase in the fraction of free $\mathrm{O}^{2-}$ ions that results from increasing the $\mathrm{CaO} / \mathrm{SiO}_{2}$ ratio is a dominant factor affecting the activity coefficient of $\mathrm{MnO}$ in the $\mathrm{CaO}-\mathrm{SiO}_{2}-\mathrm{MnO}$ slag system.

\subsection{Structure of the $\mathrm{CaO}-\mathrm{SiO}_{2}-\mathrm{MnO}-\mathrm{MgO}\left(-\mathrm{Al}_{2} \mathrm{O}_{3}\right)$ Slag}

The symmetric $\mathrm{Si}-\mathrm{O}$ stretching bonds at about $1150-800$ $\mathrm{cm}^{-1}$ extend to about $1150-760 \mathrm{~cm}^{-1}$ with increasing $\mathrm{MgO}$ content as shown in Fig. 7(a), indicating that the silicate network is more depolymerized at higher $\mathrm{MgO}$ content. The activity coefficient of $\mathrm{MnO}$ in the $\mathrm{CaO}-\mathrm{SiO}_{2}-\mathrm{MnO}-\mathrm{MgO}$ system increases as the $\mathrm{MgO}$ content increases (Fig. 4) because the $\mathrm{MgO}$ behaves as a basic oxide. Moreover, the fraction of free $\mathrm{Mn}^{2+}$ cations from the network-modifying role increases with increasing $\mathrm{MgO}$ content because the silicate units are charge-balanced with plenty of $\mathrm{Mg}^{2+}$ and $\mathrm{Mn}^{2+}$ ions. ${ }^{24}$

Alumina is known to substitute for tetrahedral sites in aluminosilicate melts when the sum of charge-balancing basic oxides is higher than the content of $\mathrm{Al}_{2} \mathrm{O}_{3}{ }^{25-28)}$ In Fig. 7(b), the relative fraction of $\left[\mathrm{AlO}_{4}\right]$-tetrahedra increases with the increasing content of $\mathrm{Al}_{2} \mathrm{O}_{3}$ as a result of the fact that the band at $800-600 \mathrm{~cm}^{-1}$, which corresponds to the $\left[\mathrm{AlO}_{4}\right]$-tetrahedral bond, ${ }^{22,23)}$ becomes more pronounced as the $\mathrm{Al}_{2} \mathrm{O}_{3}$ content increases. The alternating arrangement of $\mathrm{Al}$ and $\mathrm{Si}$ is a manifestation of Loewenstein's aluminumavoidance rule, ${ }^{29)}$ which states that $\mathrm{Al}-\mathrm{O}-\mathrm{Al}$ linkages between aluminate tetrahedra are energetically unfavorable compared to the $\mathrm{Si}-\mathrm{O}-\mathrm{Al}$ linkage. Thus, the aluminosilicate structure, i.e., the $\mathrm{Si}-\mathrm{O}-\mathrm{Al}$ linkage, should increase with

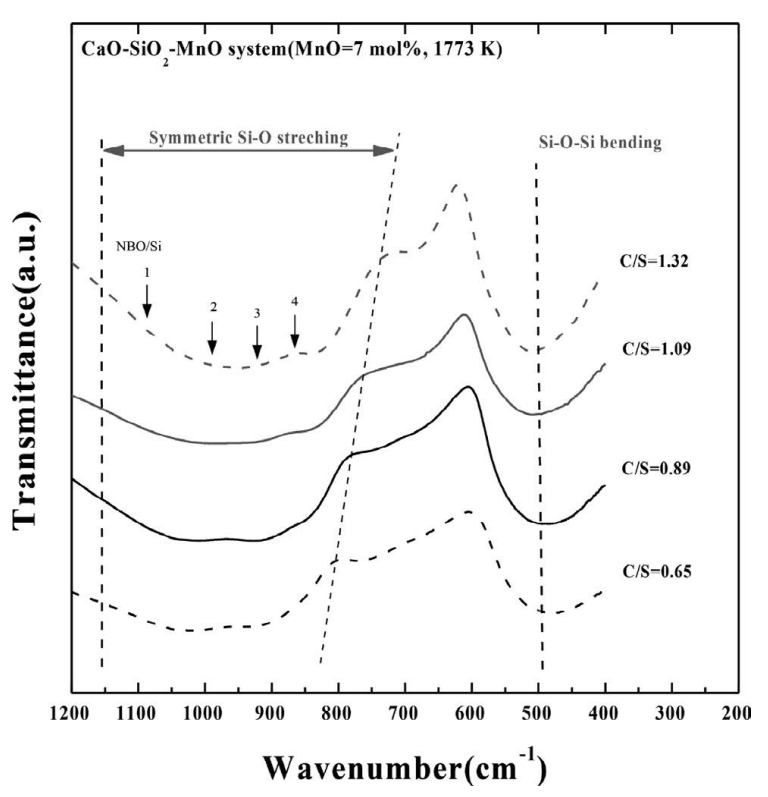

Fig. 6. IR-transmittance of the $\mathrm{CaO}-\mathrm{SiO}_{2}-\mathrm{MnO}$ slag system as a function of wavenumber at different $\mathrm{CaO} / \mathrm{SiO}_{2}$. 
(a)

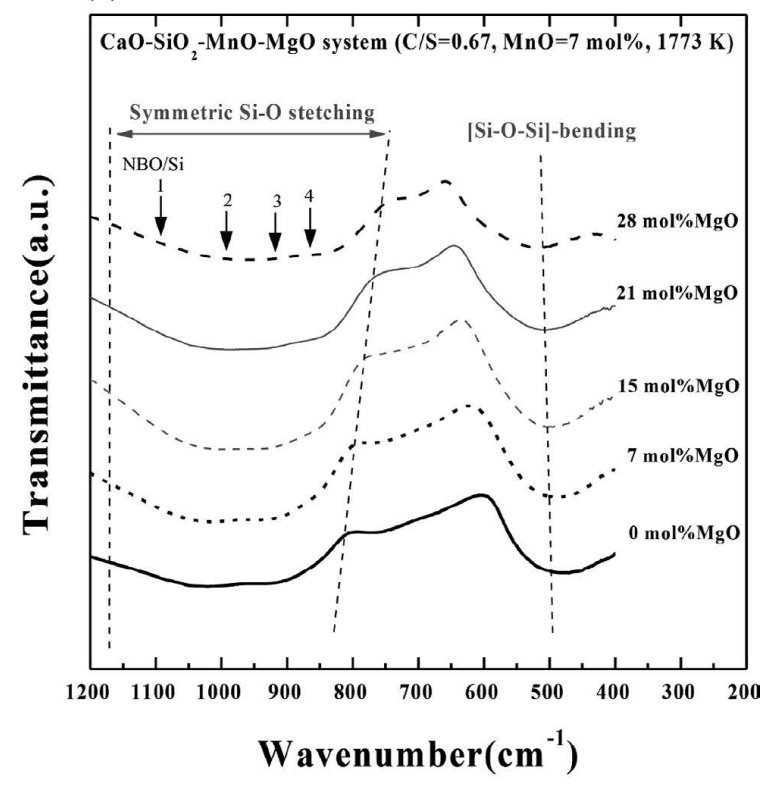

(b)

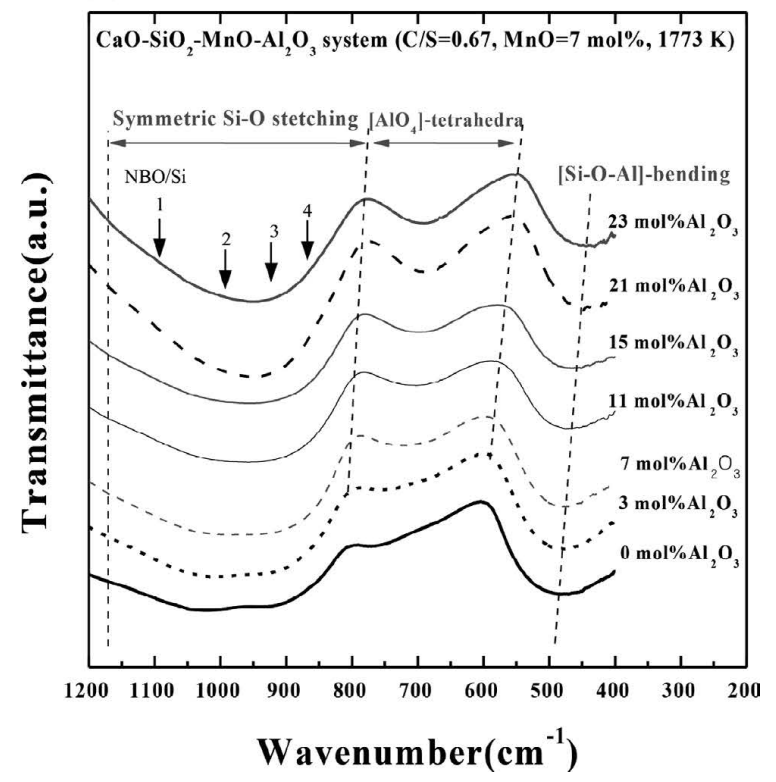

Fig. 7. IR-transmittance of (a) $\mathrm{CaO}-\mathrm{SiO}_{2}-\mathrm{MnO}-\mathrm{MgO}$ and (b) $\mathrm{CaO}-\mathrm{SiO}_{2}-\mathrm{MnO}-\mathrm{Al}_{2} \mathrm{O}_{3}$ slag system $(\mathrm{C} / \mathrm{S}=0.67)$ as a function of wavenumber.

increasing $\left[\mathrm{AlO}_{4}\right]$-tetrahedra in the $\mathrm{CaO}-\mathrm{SiO}_{2}-\mathrm{MnO}-\mathrm{Al}_{2} \mathrm{O}_{3}$ system, viz. $\left.(\mathrm{Si}-\mathrm{O}-\mathrm{Si})+(\mathrm{Al}-\mathrm{O}-\mathrm{Al})=2(\mathrm{Si}-\mathrm{O}-\mathrm{Al}) \cdot{ }^{10}\right)$ Seifert ${ }^{32)}$ reported that the proportions of ring types in melts, which are the $\mathrm{Si}-\mathrm{O}-\mathrm{Si}, \mathrm{Si}-\mathrm{O}-\mathrm{Al}$, and $\mathrm{Al}-\mathrm{O}-\mathrm{Al}$ linkages, depend on the $\mathrm{Al} /(\mathrm{Al}+\mathrm{Si})$ ratio in the $\mathrm{CaAl}_{2} \mathrm{O}_{4}-\mathrm{SiO}_{2}$ system. According to this article, the $\mathrm{Si}-\mathrm{O}-\mathrm{Si}$ linkage (six-membered $\mathrm{SiO}_{2}$ rings) decreases, whereas the $\mathrm{Si}-\mathrm{O}-\mathrm{Al}$ linkage (four-membered $\mathrm{Al}_{2} \mathrm{Si}_{2} \mathrm{O}_{8}{ }^{2-}$ rings) increases with $\mathrm{Al}_{2} \mathrm{O}_{3}$ content up to an $\mathrm{Al} /(\mathrm{Al}+\mathrm{Si})$ ratio of 0.67 . Also, the $\mathrm{Al}-\mathrm{O}-\mathrm{Al}$ linkage (six-membered $\mathrm{Al}_{2} \mathrm{O}_{4}{ }^{2-}$ rings) appears and increases above an $\mathrm{Al} /(\mathrm{Al}+\mathrm{Si})$ ratio of 0.4. The $\mathrm{Al}-\mathrm{O}-\mathrm{Al}$ linkage increases dramatically above an $\mathrm{Al} /(\mathrm{Al}+\mathrm{Si})$ ratio of 0.67 , whereas the $\mathrm{Si}-\mathrm{O}-\mathrm{Al}$ linkage decreases with the increasing $\mathrm{Al} /(\mathrm{Al}+\mathrm{Si})$ ratio. Therefore, the structure in the $\mathrm{CaO}-\mathrm{SiO}_{2}-\mathrm{MnO}-\mathrm{Al}_{2} \mathrm{O}_{3}$ system should change from that of the $\mathrm{Si}-\mathrm{O}-\mathrm{Si}$ linkage to that of the $\mathrm{Si}-\mathrm{O}-\mathrm{Al}$ and $\mathrm{Al}-\mathrm{O}-\mathrm{Al}$ linkages with increasing $\mathrm{Al}_{2} \mathrm{O}_{3}$ content.

In the $\mathrm{CaO}-\mathrm{SiO}_{2}-\mathrm{MnO}$ system, $\mathrm{Mn}^{2+}$ is able to occupy the $\mathrm{Q}^{2}$ site, whose glass structure in this case is dominated by the $\mathrm{Si}-\mathrm{O}-\mathrm{Si}$ linkage ${ }^{30)}$ because the $\left[\mathrm{MnO}_{6}\right]$ cage is smaller than the $\left[\mathrm{CaO}_{6}\right]$ cage. ${ }^{11)}$ In the $\mathrm{CaO}-\mathrm{SiO}_{2}-\mathrm{MnO}-$ $\mathrm{Al}_{2} \mathrm{O}_{3}$ system, $\mathrm{Mn}^{2+}$ is favorable to occupy the $\mathrm{Q}^{2}$ site as before. The Si-O-Al linkage formed by the $\mathrm{Al}_{2} \mathrm{O}_{3}$ content is balanced with $\mathrm{Ca}^{2+}$, whose glass structure is dominated by a series of glasses of the formula $\mathrm{CaAl}_{2} \mathrm{O}_{4} \cdot \mathrm{nSiO}_{2}(\mathrm{n}=$ $1,2,4,6,12$, depending on the $\mathrm{Si} / \mathrm{Al}$ ratio $)^{24)}$ because of the preference of $\mathrm{Si}-\mathrm{O}-\mathrm{Al}$ linkage with alkali cations. ${ }^{28)}$ Therefore, the number of free $\mathrm{Mn}^{2+}$ cations increases with increasing content of $\mathrm{Al}_{2} \mathrm{O}_{3}$ because the $\mathrm{Si}-\mathrm{O}-\mathrm{Si}$ linkage decreases as the $\mathrm{Al}_{2} \mathrm{O}_{3}$ content increases. ${ }^{32)}$ In this way, the activity coefficient of $\mathrm{MnO}$ increases with the increasing $\mathrm{Al}_{2} \mathrm{O}_{3}$ content (Fig. 4) owing to an increase in the number of free $\mathrm{Mn}^{2+}$ cations, which results from changing the silicate melt to an aluminosilicate melt. However, the activity coefficient of $\mathrm{MnO}$ decreases with increasing $\mathrm{Al}_{2} \mathrm{O}_{3}$ content above $20 \mathrm{~mol} \% \mathrm{Al}_{2} \mathrm{O}_{3}$ because the $\mathrm{Al}-\mathrm{O}-\mathrm{Al}$ linkages $\left(\mathrm{Al}_{2} \mathrm{O}_{4}{ }^{2-}\right)$, which are charge-balanced with $\mathrm{Mn}^{2+}$ to increase the activity of $\mathrm{MnAl}_{2} \mathrm{O}_{4},{ }^{31,33)}$ appear above $20 \mathrm{~mol} \% \mathrm{Al}_{2} \mathrm{O}_{3}$, which corresponds to about $\mathrm{Al} /(\mathrm{Al}+\mathrm{Si})=0.4$ in present slag system.

\subsection{Examination of Manganese Distribution between $\mathrm{CaO}-\mathrm{SiO}_{2}-\mathrm{MnO}\left(-\mathrm{MgO}, \mathrm{Al}_{2} \mathrm{O}_{3}\right)$ Slag and Molten Fe-Mn-Si-C}

The equilibrium between $\mathrm{CaO}-\mathrm{SiO}_{2}-\mathrm{MnO}\left(-\mathrm{MgO}, \mathrm{Al}_{2} \mathrm{O}_{3}\right)$ slag and the $\mathrm{Fe}-\mathrm{C}$ melt was carried out under a strongly reducing atmosphere to simulate the smelting reduction of $\mathrm{MnO}$ in the silicomanganese slag. Equilibrium compositions are listed in Table 2. The results from the equilibrium test indicated that manganese and silicon were distributed between metal and slag phases because $\mathrm{MnO}$ and $\mathrm{SiO}_{2}$ follow the couple reaction at the slag/metal interface, which is given by: ${ }^{34-37)}$

$$
\begin{aligned}
& 2 \mathrm{MnO}(s)+\mathrm{Si}(\mathrm{l})=\mathrm{SiO}_{2}(\mathrm{l})+2 \mathrm{Mn}(\mathrm{l}) \\
& \Delta G^{\circ}=-147946+32.68 \mathrm{~T}(\mathrm{~J} / \mathrm{mole} \cdot \mathrm{K})
\end{aligned} .
$$

The distribution ratio of $\mathrm{Mn}$ between the slag and $\mathrm{Fe}-\mathrm{Mn}-$ $\mathrm{Si}-\mathrm{C}$ can be obtained by Eq. (4):

$$
\log L_{M n}=\log \left(\frac{X_{M n O}}{X_{M n}}\right)=\log \left(\frac{\gamma_{M n}}{\gamma_{M n O}}\right)+\frac{1}{2} \log \left(\frac{a_{S i O_{2}}}{a_{S i}} \cdot \frac{1}{K_{1}}\right),
$$

where $X_{\mathrm{Mn}}$ and $\gamma_{\mathrm{Mn}}$ are the mole fraction and activity coefficient of $\mathrm{Mn}$ in the $\mathrm{Fe}-\mathrm{Mn}-\mathrm{Si}-\mathrm{C}$, respectively, $a_{\mathrm{SiO}_{2}}$ is the activity of $\mathrm{SiO}_{2}$ in the slag, and $a_{S i}$ is the activity of $\mathrm{Si}$ in $\mathrm{Fe}-\mathrm{Mn}-\mathrm{Si}-\mathrm{C}$.

The logarithmic value of the Mn distribution ratio $\left(\mathrm{L}_{\mathrm{Mn}}\right)$ is inversely proportional to the logarithmic value of the $\gamma_{\mathrm{MnO}}$ as shown in Fig. 8. As mentioned in previous section 3 , the $\gamma_{M n O}$ is obtained by the equilibrium between molten slag and $\mathrm{Cu}$. Since $\mathrm{FeO}$ concentration is lesser than 0.5 mol\% in present work, the effect of $\mathrm{FeO}$ would be ignored. ${ }^{9)}$ Moreover, Fig. 8 indicates the correlation between $\gamma_{M n O}$ and the degree of reduction for $\mathrm{MnO}$ in slag as an index of the recovery of Mn. Accordingly, the degree of Mn reduction 


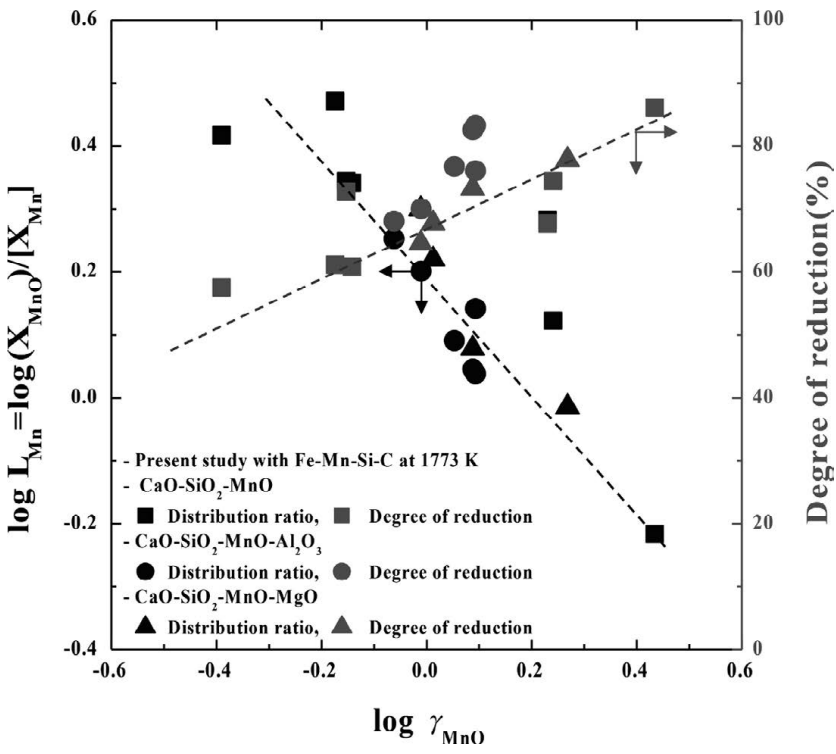

Fig. 8. Dependence of the $\gamma_{\mathrm{MnO}}$ on the distribution ratio or degree of reduction of $\mathrm{MnO}$ between $\mathrm{CaO}-\mathrm{SiO}_{2}-\mathrm{MnO}(-\mathrm{MgO}$, $\mathrm{Al}_{2} \mathrm{O}_{3}$ ) slag and $\mathrm{Fe}-\mathrm{Mn}-\mathrm{Si}-\mathrm{C}$ at $1773 \mathrm{~K}$.

can be defined as follows:

$$
\begin{aligned}
& \text { Degree of Mn reduction (\%) } \\
& =\frac{W_{\text {slag }}^{\text {initial }} \times w t \% M n O_{\text {in slag }}^{\text {initial }}-W_{\text {slag }}^{\text {final }} \times w t \% M n O_{\text {in slag }}^{\text {final }}}{W_{\text {slag }}^{\text {initial }} \times w t \% M n O_{\text {in slag }}^{\text {initial }}} \times 100,
\end{aligned}
$$

where $W_{\text {Metal }}$ and $W_{\text {Slag }}$ are the weight of the metal and slag, respectively, and $M_{i}$ is the molecular mass of component $i$. The degree of $\mathrm{Mn}$ reduction increases linearly with increasing activity coefficient of $\mathrm{MnO}$.

\section{Conclusions}

In order to understand the thermodynamic behavior of $\mathrm{MnO}$ in slag, the activity coefficient of $\mathrm{MnO}$ was measured in the molten $\mathrm{CaO}-\mathrm{SiO}_{2}-\mathrm{MnO}\left(-\mathrm{MgO}, \mathrm{Al}_{2} \mathrm{O}_{3}\right)$ slag system at $1773 \mathrm{~K}$ using molten $\mathrm{Cu}$. The concept of modified basicity was employed in this measurement, and its effect was compared with that in various other slag systems. On the basis of the results of our study, we may draw the following conclusions.

(1) The activity coefficient of $\mathrm{MnO}$ in the $\mathrm{CaO}-\mathrm{SiO}_{2}-$ $\mathrm{MnO}$ slag system is influenced by the $\mathrm{MnO}$ contents of the slag and slag composition (basicity and additional elements).

(2) The activity coefficient of $\mathrm{MnO}$ is not affected by its own concentration up to about $30 \mathrm{~mol} \% \mathrm{MnO}$ because $\mathrm{Mn}^{2+}$ should be balanced with $\mathrm{Q}^{2}$ corner-shared $\mathrm{O}^{-}$ions, beyond which it slightly increases at a $\mathrm{CaO} / \mathrm{SiO}_{2}$ ratio of 0.54 .

(3) The activity coefficient of $\mathrm{MnO}$ increases with an increase in the modified basicity, which is represented by the $(\mathrm{CaO}+\mathrm{MgO}+\mathrm{FeO}) / \mathrm{SiO}_{2}$ ratio, because an increase in the fraction of free $\mathrm{O}^{2-}$ ions is a dominant factor in affecting the activity coefficient of $\mathrm{MnO}$ in the $\mathrm{CaO}-\mathrm{SiO}_{2}-$ $\mathrm{MnO}(-\mathrm{MgO})$ slag system.

(4) The activity coefficient of $\mathrm{MnO}$ is affected by the
$\mathrm{Al}_{2} \mathrm{O}_{3}$ content because the structure in the $\mathrm{CaO}-\mathrm{SiO}_{2}-\mathrm{MnO}-$ $\mathrm{Al}_{2} \mathrm{O}_{3}$ system should be changed from that of the $\mathrm{Si}-\mathrm{O}-\mathrm{Si}$ linkage to that of the $\mathrm{Si}-\mathrm{O}-\mathrm{Al}$ and $\mathrm{Al}-\mathrm{O}-\mathrm{Al}$ linkages with the increasing content of $\mathrm{Al}_{2} \mathrm{O}_{3}$. The activity coefficient of $\mathrm{MnO}$ increases with the increasing $\mathrm{Si}-\mathrm{O}-\mathrm{Al}$ linkage and decreases with the increasing $\mathrm{Al}-\mathrm{O}-\mathrm{Al}$ linkage because $\mathrm{Mn}^{2+}$ can be charge balanced with the $\mathrm{Q}^{2}$ site dominated by the $\mathrm{Si}-\mathrm{O}-\mathrm{Si}$ and $\mathrm{Al}-\mathrm{O}-\mathrm{Al}$ linkages.

(5) The degree of $\mathrm{Mn}$ reduction increases linearly with increasing activity coefficient of $\mathrm{MnO}$ in the $\mathrm{CaO}-\mathrm{SiO}_{2}-$ $\mathrm{MnO}\left(-\mathrm{MgO}, \mathrm{Al}_{2} \mathrm{O}_{3}\right)$ slag system in equilibrium with the $\mathrm{Fe}-\mathrm{Mn}-\mathrm{Si}-\mathrm{C}$.

\section{Acknowledgments}

This work was supported by the third Stage of Brain Korea 21 Plus Project and the Industrial Strategy Technology Development (No. 10033389, Development of e-FERA Technology) through a grant provided by the Ministry of Knowledge Economy.

\section{REFERENCES}

1) O. Grässel, L. Krüger, G. Frommeyer and L. W. Meyer: Int. J. Plast., 16 (2000), 1391.

2) Y. Huang, A. M. Zhao, Z. L. Mi, H. T. Jing, W. Y. Li and Y. J. Hui: J. Iron Steel Res. Int., 20 (2013), 111.

3) D. J. Min and R. J. Fruehan: Trans. ISS, 13 (1992), 47.

4) A. A. Aleksandrov, V. Ya. Dashevskii and L. I. Leont'ev: Steel Transl., 43 (2013), 661.

5) K. P. Abraham, M. W. Davied and F. D. Richardson: J. Iron Steel Inst., 196 (1960), 82.

6) S. R. Simeonov and N. Sano: Trans. Iron Steel Inst. Jpn., 25 (1985), 1116.

7) A. T. Morales and R. J. Fruehan: Metall. Trans. B, 28B (1997), 1111.

8) H. Suito and R. Inoue: Trans. Iron Steel Inst. Jpn., 24 (1984), 257.

9) H. Suito and R. Inoue: ISIJ Int., 35 (1995), 266.

10) B. Mysen: Eur. J. Mineral., 15 (2003), 781.

11) J. H. Park: J. Non-Cryst. Solids, 358 (2012), 3096.

12) J. H. Park: Met. Mater. Int., 19 (2013), 577.

13) J. H. Park: Steel Res. Int., 84 (2013), 664.

14) J. H. Park, D. J. Min and H. S. Song: ISIJ Int., 42 (2002), 344

15) E. T. Turkdogan: Physical Chemistry of High Temperature Technology, Academic Press, New York, (1980), 5.

16) S. M. Jung, C. H. Rhee and D. J. Min: ISIJ Int., 47 (2007), 1699.

17) S. M. Jung, D. J. Min and C. H. Rhee: Mater. Trans., JIM, 37 (1996), 916.

18) A. Sobandi, H. G. Katayama and T. Momono: ISIJ Int., 38 (1998), 953.

19) H. Ohta and H. Suito: Metall. Trans. B, 26B (1995), 295.

20) J. H. Park: ISIJ Int., 52 (2012), 1627.

21) P. McMillan: Am. Mineral., 69 (1984), 645.

22) H. Kim, W. H. Kim, J. H. Park and D. J. Min: Steel Res. Int., 81 (2010), 17.

23) W. H. Kim, I. Sohn and D. J. Min: Steel Res. Int., 81 (2010), 735.

24) J. B. Murdoch and J. F. Stebbins: Am. Mineral., 70 (1985), 332.

25) P. McMillan: J. Non-Cryst. Solids, 53 (1982), 279.

26) B. O. Mysen, D. Virgo and C. M. Scarfe: Am. Mineral., 65 (1980), 690.

27) B. O. Mysen, D. Virgo and I. Kushiro: Am. Minerral., 66 (1981), 678.

28) M. Taylor and G. E. Brown: Geochim. Cosmochim Acta, 43 (1979), 61.

29) W. Loewenstein: Am. Mineral., 39 (1954), 92.

30) J. Etchepare: Study by Raman Spectroscopy of Crystalline and Glassy Diopside, in Amorphous Materials, ed. by R. W. Douglas and E. Ellis, Wiley-Interscience, New York, (1972), 337.

31) E. F. Osborn and A. Muan: Phase Equilibrium Diagrams of Oxide Systems, Am. Ceram. Soc., Columbus Ohio (1960), Plate 3.

32) F. Seifert, B. O. Mysen and D. Virgo: Am. Mineral., 67 (1982), 696.

33) E. J. Essene and D. R. Peacor: Am. Mineral., 68 (1983), 449.

34) W. Ding and S. E. Olsen: Metall. Trans. B, 27B (1996), 5.

35) W. J. Rankin: Trans. Inst. Min. Met. Sec. C, 88 (1979), 167.

36) D. R. Swinbourne, W. J. Rankin and R. H. Eric: Metall. Trans. B, 26B (1995), 59.

37) R. S. Darken and R. W. Gurry: Physical Chemistry of Metals, McGraw-Hill, New York, (1953), 144. 